\title{
The Effective Application of Computer Aided Teaching in Intellectual Disabled Children Education Development
}

\author{
Zhang Mei \\ Special education department, Leshan normal University, Ieshan, sichuan,614000,China
}

Keywords: The United States; Computer assisted instruction; Intellectual disabled children education;

\begin{abstract}
Specialized education of intellectual disabled children is an important part of social education. Because of congenital disorder, children lack their own learning function, which causes more difficulties to accept high quality education in the process of education, so special education has to be applied. In the development of modern society, the emergence of new type computer assisted instruction, to a great extent, has improved the effect, and improved the oneness of different models on the basic quality differences. In corresponding social education responsibility, it also embodies its own unique education properties.
\end{abstract}

According to the construction and development of modern economic system, in the process of new technology innovation, apply modern teaching mode for course ware development and application, and it has been in an important part of special education system according to the adjustment of teaching effect. The application of modern education technology is auxiliary to the basic education of intellectual disabled children, which makes it an important technology of modern education reform. In this paper, computer aided teaching is taken as a starting point for the contrasted analysis of education development of our country in this respect.

\section{THE SPECIAL EDUCATION VALUE OF COMPUTER AIDED TEACHING}

With the rapid development of modern society, the education construction of special children has been able to gradually realize education guidance and create a better information management through modern education system. In such an effective education environment, computer aided education counseling teaching has its significance, which is in the following points.

A. The importance of special education environment

From the perspective of modern education informationization development, the application field of modern computer education is reforming in accordance with computer network technology, and plays a role in comprehensive education reform, etc. It can better emphasize its teaching informationization reform progress. And on the basis of the existing education system, improve construction and its education informatization construction core is the application of modern technology in special education.

Computer assisted instruction can let special children group receive the similar education environment to that of normal children. This has a good role in promoting its own development and so on. In informatization auxiliary teaching, since 2009 in our country, it has basically achieved the all-round education infrastructure construction, and has reflected certain role in education effect in recent years. On the point of modern teaching, the application of effective information technology in education is an important technology reform to improve our country's students' information literacy ability. So its importance is self-evident.

$B$. The promotion effect of teaching quality under assisted environment

In the construction of modern teaching reform means in our country, the application of full information technology means for the disabled education model reconstruction, through formulations of the corresponding teaching plan, let more children gain better education, which is in the breakthroughs of modern teaching reform in our country. From the case of three times reforms in the history of our country's education, the application of computer assisted instruction to promote 
comprehensive reform on teaching thought is a certain effective innovation of teaching mode, and an important means to promote students' ability in personal promotion. Application of computer auxiliary functions not only improves the control function of students in different environment and will be better able to assist students to understand the wider world in the individualized teaching process at the same time.

\section{The significant effect of computer aided mode}

From modern teaching form, the application of computer aided technology can greatly promote students' individual ability development in intellectual environment, and through the improvement of their personal physiological defect level, achieve teaching experience accumulation in intuitive features, and provide students with more complete knowledge system based on facts abstract expression, and let them gain a better understanding effect, thereby increase their effective intelligence development.

\section{MANY PROBLEMS IN MODERN COMPUTER AIDED TEACHING}

From the beginning of new education system reform in our country, in special education resources teaching environment, conduct a comprehensive facilities education construction with the application of the existing information education resources. Its own role also can better promote the specification of computer information technology application. But in the form of construction education, there are many problems and the main problems are focused on the following points.

\section{A. Modern informationization teaching resources shortage}

From modern education forms development in our country, the greatest weakness lies in that the quantity and quality of teaching resources can't compare with that of the United States and other countries. In the software development of special education in our country, mainly apply the adaptations of foreign software. In use, they cannot make an effective education system. At the same time, in modern education intelligence development and the analysis of audio-visual obstacles, we need to realize the situation analysis of different students through the establishment of special education information resources. But the shortage of informationization teaching resources in our country affects education system construction in the environment and finally affects the basic application education mechanism in our country. And through the primary intellectual disabled children teaching at this stage, these resources shortages can lead to the imperfect education system in the process of education. This is one of the important factors affecting the quality of education.

And from the hardware point of view, computers applied in special education in our country are outdated equipment, and a lot of software applications cannot be invested. This is the important factor affecting modern teaching. In the remote area, computer facilities are mostly below 98 applications, while modern disability assistance software are system software over 98, which seriously impacts the popularization and application of multimedia teaching.

B. Single education model leading to computer education popularization difficulties

From the modern teaching mode form, in special children education in our country, single teaching mode seriously causes the fact that materials cannot be covered in the process of teaching, and computer aided system cannot be able to be effectively carried out, resulting in text, images, animation and so on are only superficial in education and are unable to achieve effective information makeup. According to our country's current auxiliary teaching software, computer aided special teaching receives good teaching effect in application, and obtains widespread social recognition. But in the process of promoting, lack of resources leads to construction lag, which also is the important factor affecting modern student information literacy training, and the fundamental factor in special education implementation difficulties.

C. The shortage of resources suitable for modern disabled students

From the current situation of modern disabled students' skills learning process in China's, their individual performance form cannot be compared with that of normal students. So in the choice of learning resources, need to make up through corresponding facilities, but in the process of modification, due to the shortage of teaching resources for the disabled students, their teaching behavior cannot be truly be comprehensive implemented, which seriously influence our country's 
modern special teaching implementation. Its reason lies in the shortage of teaching resources.

III. THE REFORM STRATEGIES SUITABLE FOR MODERN DISABLED STUDENTS TEACHING RESOURCES

Disabled children have congenital absence of the convenient life ability of normal children. On special education ability training, still require a combination of general education for social survival skills learning, and the amount of effort is several times of normal children. From the body reform strategy analysis of modern teaching auxiliary education forms, adjust the reform and the specific strategies are as follows.

A. Conceptual change adjustment

In teaching system reform process, conduct a comprehensive adjustment from conception. This is to ensure the teaching. Through carrying out on special children teaching reform policy in China, construct corresponding information-based education hardware strategy. Through informationization society construction, complete education construction on The Times reform change, and intensely construct special field construction with computer assisted instruction to raise the education level of disabled children.

In technology thinking and innovation, education level management reform under the teaching form environment realizes the protection of original information. In computer assisted instruction, strengthen the investment of hardware resources, such as the input to a computer system, replace the old equipment. For resources update problem, pay attention to three issues. First, teaching resources training effect should intensify development. Second, in the developed areas, cooperate with the appropriate teaching resources and attaches great importance to it, and encourage students to attend public course. Third, encourage the public for teaching resources website construction. Through the education protection of disabled students, better enrich the teaching resources information adjustment.

\section{$B$. The integration of the existing higher education resources}

In the modern education system in our country, the number of graduate professional talents is increasing year by year, of which the number of special education graduates still cannot fully meet the teaching development of modern society. So we need make various education adjustment combined with the actual social digital teaching concept. For special education resources construction, we should pay attention to the following aspects. First, from the overall advantages of disciplines, complete the student's education resources construction, and at the same time, strengthen the information resource education of education researchers. Second, overcome the existing social education obstacles and take practice as the main strategy of teaching reform to realize the restructuring application of resource information. Among these, teachers need to combine with the actual classroom strategy for resource restructuring to avoid the insufficient development of resources and lead to vague teaching effect.

C. Encourage high qualified teachers' innovation in modern teaching technology

In the teaching of special groups, we should strengthen the depth of reform system implementation as an important education relief. Focus the teaching tasks on the cognitive teaching on special groups, and achieve mastery of new technology in teacher's personal organization. Second, encourage teachers of special education to make education cognition of computing information and actively support their media development resource adjustment, so as to realize teaching strategy implement of different terminal technologies. Make use of technology improvement, innovate teaching through traditional teaching methods so as to realize different learning stage adjustment. Teachers should make careful observation and rational utilization of resources to realize the learning skill teaching of disabled children and make them to master the corresponding ability skills.

\section{CONCLUSION}

With the education system reform of modern society in our country, it is necessary to combine with the idea of autonomous individual learning and make behavioral adjustments. In individual's ability ascendant, realize the reasonable proportion of overall education resources so as to realize the adaptation to autonomous learning environment. In order to promote the adjustment of special 
children in teaching strategy in China, it requires a combination of the actual social demand for improved adjustment on teaching facilities. Adjust teaching resources with the application of modern information technology resources equipment. This is the fundamental strategy to promote the individualized construction. The reform construction of the system has become an important strategy in the current basic education resources adjustment in our country.

The course joint project of Sichuan Federation of Social Science and Leshan Normal University: the practice research of retardation children action ability development under "Teaching, combining with health" mode (SCI4XK20)

\section{REFERENCES}

[1] Lu Jianwen. Using of multimedia technology and the Internet for the optimization of high school English reading teaching [D]. Fujian Normal University, 2003.

[2] Li Zhao. Computer assisted instruction application literature review in mental retardation education [J]. Journal of Experimental and Equipment of Primary and Secondary Schools, 2011, (4) : 37-39.

[3] Pan Zuwen. Introduction to computer aided teaching effect of mathematics teaching [J]. Journal of Education, 2014, (28) : 167-167.

[4] Xie Sen. Introduction to computer aided teaching in language classroom [J]. Journal of Education, 2010, (19) : 157.

[5] Zhang Hong'e. The application discussion of computer aided teaching in geography teaching [J]. Journal of Shanxi Normal University (Natural Science Edition), 2008, 22 (z1) : 105-106.

[6] Zhang Lu. Electronic education game application research in Yinchuan Elementary School mathematics teaching [D]. Ningxia University, 2014.

[7] Jiao Wenbin, Zhang Hua. The main impediment analysis of the integration implementation of the computer and primary and secondary school curriculum [J]. Journal of Liaoning Education, 2001, (12) : 31-32.

[8] Wabg Huifang, Zhu Siyu, Zhang Li’an. Congcong learn words ---- multimedia training system for deaf children language learning [C] Computer and Education ---- the 10th Computer Aided Education Institute Academic Conference Proceedings. 2001:365-368. 